\title{
Strategy of recreational anglers and estimated eel (Anguilla anguilla) catches in a large European catchment basin, the Loire (France)
}

\author{
A. Baisez ${ }^{(1)}$, P. Laffaille $(2)$ \\ Received September 25, 2008 / Reçu le 25 septembre 2008 \\ Revised January 20, 2009 / Révisé le 20 janvier 2009 \\ Accepted February 9, 2009 / Accepté le 9 février 2009
}

Key-words:

eel, catch, angler,

estimation, survey

\section{ABSTRACT}

The European Council Regulation (18 September 2007) for the recovery of eel stocks required European states to report on eel stocks and anthropic mortalities. The data sources for France reveal gaps in our knowledge about angling in the public domain, and catches from privately-owned rivers. We tested a simple method, using a survey, for estimating the strategy employed and the catches landed by the 350000 anglers fishing in the Loire catchment area. The first findings show that the answers of the fishermen varied between 1 and $2 \%$ in the departments with the most eels, and between 0.1 and $0.2 \%$ in the departments located further upstream. The interest in eel fishing, the average weight of the eels caught by the fishermen, and the total catch all decreased from downstream to upstream. Finally, we estimated the annual average weight of eel caught by anglers, which ranged from 0.8 to $5.3 \mathrm{~kg}$ per year depending on the department and the local interest in eel fishing. This preliminary study shows that it is possible to estimate the different fishing strategies used and the quantities caught by means of a survey.

RÉSUMÉ

Stratégie et estimation des captures d'anguilles (Anguilla anguilla) par les pêcheurs amateurs aux lignes dans un grand bassin versant européen, la Loire (France)

Mots-clés : anguille, capture, pêcheur aux lignes, estimation, questionnaire
Le règlement européen $\left(n^{\circ} 1100 / 2007\right.$ du Conseil du 18 septembre 2007) relatif à l'élaboration d'un plan de gestion de l'anguille et instituant des mesures de reconstitution du stock d'anguilles européennes spécifie de déclarer l'état des stocks et les mortalités anthropiques. Les sources de données pour la France montrent des lacunes dans nos connaissances concernant les pêcheurs amateurs aux lignes et leurs captures sur le domaine publique et privé. Nous avons testé un simple questionnaire pour estimer la stratégie employée et les captures des 350000 pêcheurs amateurs aux lignes du bassin versant de la Loire. Les premiers résultats montrent que les réponses des pêcheurs varient entre 1 et $2 \%$ pour les départements où l'anguille est abondante, entre 0,1 et $0,2 \%$ dans ceux localisés plus en amont. L'intérêt dans la pêche à l'anguille, le poids moyen des anguilles capturées et les

(1) Tableau de Bord Anguille du bassin Loire (Eel report card on the Loire catchment area), Loire GRAnds Mlgrateurs, URU 420 "Biodiversité et gestion des territoires", Campus Beaulieu, 35042 Rennes, France, tableau-anguille-loire@hotmail.fr

(2) URU 420 "Biodiversité et gestion des territoires", Service du Patrimoine Naturel, Université de Rennes 1 Muséum National d'Histoire Naturelle, Campus Beaulieu, 35042 Rennes, France, pascal.laffaille@univ-rennes1.fr 
captures totales par les pêcheurs diminuent de l'aval à l'amont. Finalement, nous pouvons estimer les captures annuelles individuelles qui varient de 0,8 à 5,3 kg en fonction des départements et de l'intérêt pour pêcher l'anguille. Cette étude préliminaire permet de montrer qu'il est possible d'estimer les différentes stratégies des pêcheurs amateurs aux lignes et leurs captures à l'aide de simples questionnaires.

\section{INTRODUCTION}

The European eel is an important resource in terms of conservation, ecology and socioeconomic considerations (Baisez and Laffaille, 2005). All continental stages (from the glass eel to the silver eel) are harvested with a mean annual global production of around 20000 metric tons of eel, corresponding to 2 billion individual eels caught per year for the whole of Europe (Dekker, 2000). In France, eel is the main catch for 776 professional fishermen, 580 of whom operate in freshwater (Changeux, 2002). This species interests around 1.5 million recreational anglers, 350000 of whom fish in the Loire catchment area. Since the 1980s, the abundance of the European eel has declined throughout its distribution range (Moriarty and Dekker, 1997; Dekker, 2003). ICES recently recommended that all means should be taken to restore the depleted stocks, at all biological stages. A stock recovery plan is urgently needed (ICES, 1999), including sustainable management (Rosell et al., 2005). It is now apparent that effective networks are essential to monitor changes in the situation of this species in order to assess the impact of the management strategies implemented, and to make it possible to preserve fishing rights and sustainable fisheries in the long term. An eel report card seemed to be the best way to measure the impact of the management measures, and to provide advice about the eel population situation, taking into account the mortality of the species on the scale of the catchment area (Baisez and Laffaille, 2005).

With regard to the continental yellow eel stage in the Loire, the eel distribution could be obtained from the sampling network of the ONEMA (the French National Office for Water and the Aquatic Environment), which covers 135 sites around the Loire catchment basin. This identified the most important eel sectors, and provided an indication of current densities, and of spatial and temporal trends (Lasne et al., 2007; Lasne and Laffaille, 2008). These densities made it possible to identify the administrative areas (departments) around the Loire that were most implicated in the management of the species. The other departments, with few eels or none at all, are generally located upstream of the catchment area. Some of them include sections of rivers that are isolated by insurmountable dams.

With the development of the leisure society, for some species recreational fishing is becoming more profitable than commercial and industrial exploitation. The assessment of the impact of anglers on fish stocks is a very controversial issue (Coleman et al., 2004; Arlinghaus et al., 2005; Morales-Nin et al., 2005). Recreational fishing is one of the most popular leisure activities in coastal zones; it involves large numbers of people, and consequently high levels of fishing, which may outweigh commercial fishing. Finally, commercial and recreational fishing have similar demographic and ecological effects on the populations fished, and they can have equally serious ecological and economic consequences. The catches of eels made by professional fishermen and by recreational anglers using traps are relatively well-established in France (national survey). However, little is known about the pressure of recreational line fishing on the European scale, and especially in the Loire basin, although there have been some local attempts to estimate the fishing pressure of anglers on eel in France (see Working Group on Eel, 2008). Recreational fishing has economic, social and cultural roles. Finally, recreational fishing must clearly be taken into account when considering the measures for managing fisheries introduced since the establishment of the eel management plan at the EU level (Council Regulation EC No 1100/2007 of 18 September 2007).

So far, there has been little investigation of recreational eel fishing, although this has not prevented the introduction of some management measures. The aim of this study was 
therefore to contribute to knowledge about the current exploitation of eel by recreational fishing on the scale of the catchment area, and hence to provide essential management data (Coleman et al., 2004; Morales-Nin et al., 2005). In 2005, the eel report card on the Loire catchment area (Baisez and Laffaille, 2005) included centralized assessments of anglers' fishing data, and especially relating to recreational line fishing. This investigation was commissioned by the Loire basin Board of Management of Migratory Fish, who wanted to find out the size of the eel catches taken by members of angling clubs (who use lines in the public areas, and are allowed to use traps on private stretches of rivers). This study presents this investigation and the first results.

The principle of the investigation was to describe the strategies used and the catches taken in the different departments by taking into account the number and characteristics of the recreational anglers using lines, and of the eels they caught. The five aspects used to determine this indicator were as follows:

(1) Characteristics of the recreational angler;

(2) Estimate of the mean annual catch landed per angler according to the department and the characteristics of the angler;

(3) Estimate of the mean weight of the eels caught;

(4) Extrapolation of these catches and weights to all the anglers fishing on the department scale;

(5) Estimate on the scale of the whole Loire catchment basin.

\section{MATERIALS AND METHODS}

\section{$>$ STUDY AREA}

The Loire is the longest French river (1012 km long), and drains a $118000-\mathrm{km}^{2}$ catchment area (Figure 1). The total length of the river network is estimated to be $107000 \mathrm{~km}$. The main axis of the basin (i.e. the Loire River, and its main upstream tributary, the Allier River) is less regulated and presents better longitudinal connectivity than the other tributaries (including large rivers), some of which are substantially impeded. The Loire itself is a relatively freeflowing river, and there are no significant barriers to migration in its lower reaches (the first one is $>500 \mathrm{~km}$ upstream of the tidal limit). Consequently, the Loire basin is often considered as being less impacted than other large river systems in Europe (Lasne et al., 2007). In contrast, most of its tributaries have been largely regulated by barriers that fish may or may not be able to get through. For example, the density of weirs or vertical dams is particularly high (> 25 per $100 \mathrm{~km}$ ) in the main part of the Maine catchment area, even in the most downstream reaches (the first weir is located only $7 \mathrm{~km}$ upstream of the confluence with the Loire River). This territory extends over 28 local administrative areas, known as departments (Figure 1).

\section{$>$ DATA SET}

On the department scale, the different federations of anglers taking part in this project contacted their members directly or indirectly, via the local angling clubs. The survey was launched in 2004 over the whole of the catchment area, and the first results were scheduled for 2005. Four questions were addressed:

- How the angler categorized him- or herself (three categories: never interested in eel; occasionally interested in eel; often interested in eel);

- Fishing methods used (multi-species, eel-specific, or both);

- Number of fishing days in 2004;

- Number and weight $(\mathrm{kg})$ of eels fished in 2004. 

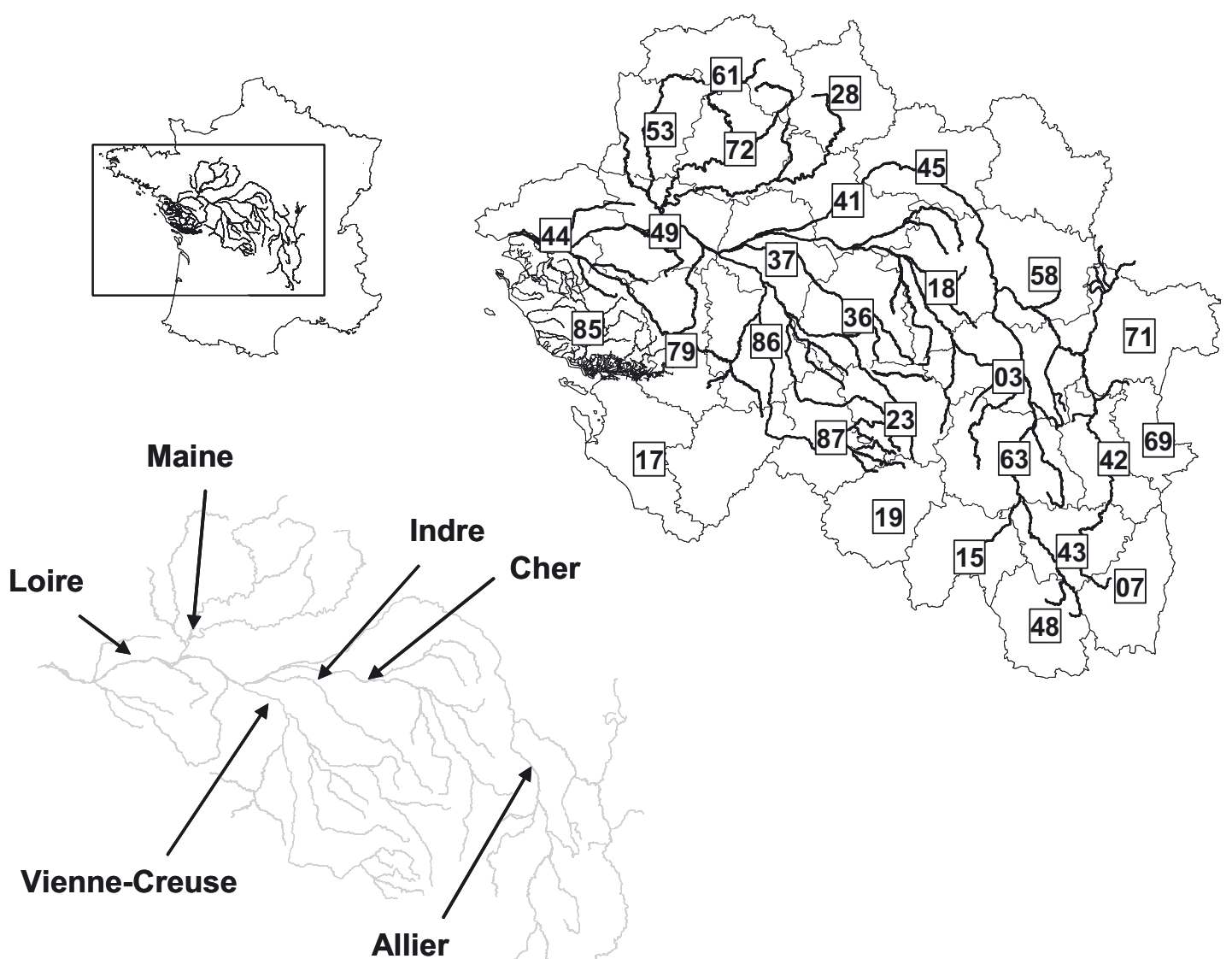

Figure 1

Location of the study site, showing with number of departments and mean rivers.

Figure 1. Localisation du site d'étude, des départements $\left(n^{\circ}\right)$ et des principales rivières.

The survey was conducted on a voluntary basis. The stratification on the large scale compensated for the bias introduced by the fact that more answers were provided by the anglers who were more interested in eel. The methods used made it possible to decide whether the stratification of the anglers corresponded to the techniques chosen, and the success rate of the fishing sessions.

The number of fishing days gave a more accurate assessment of the meaning of the three categories in terms of fishing effort. The total number of anglers was known from the number of annual individual permits issued (compulsory fees are payable in freshwater zones in order to be allowed to fish). In the departments taken into account, it was possible to estimate the total weight of eel landed: number of fishermen $x$ percentage of fishermen per category $x$ mean weight of eels fished. Finally, the number and weight of the eel caught were used to estimate the total catch for the entire Loire basin $(=$ total number of anglers $\times$ mean weight of eel fished per angler).

\section{RESULTS}

\section{$>$ THE ANSWERS}

In 2005, nine federations, representing about 145000 anglers, provided interpretable answers to the questions about the characteristics of the anglers, but only six responded to 


\section{Table I}

Total number of anglers and of answers provided according to department.

Tableau 1

Nombre total de pêcheurs amateurs aux lignes et des réponses apportées aux questionnaires en fonction des départements.

\begin{tabular}{|l|c|c|c|c|c|}
\hline \multirow{2}{*}{$\begin{array}{l}\text { Name and }\left(\mathrm{n}^{\circ}\right) \\
\text { of department }\end{array}$} & $\begin{array}{c}\text { Number } \\
\text { of } \\
\text { anglers }\end{array}$ & $\begin{array}{c}|c| \\
\text { Fishermen } \\
\text { category }\end{array}$ & $\begin{array}{c}\text { Fishing } \\
\text { method }\end{array}$ & $\begin{array}{c}\text { Biomass } \\
\text { of eels }\end{array}$ & $\begin{array}{c}\text { Number of } \\
\text { fishing days }\end{array}$ \\
\cline { 4 - 6 } & 12662 & 23 & 23 & 24 & \\
\hline Allier (3) & 8581 & 143 & 143 & 142 & \\
\hline Indre (36) & 15330 & 162 & 161 & 161 & \\
\hline Loir-et-Cher (41) & 7532 & 55 & 55 & 55 & 55 \\
\hline Loire-Atlantique (44) & 22778 & 13801 & 323 & 309 & 232 \\
\hline Maine-et-Loire (49) & 29847 & 8748 & & & 106 \\
\hline Mayenne (53) & 10800 & 107 & 87 & 93 & \\
\hline Sarthe (72) & 22260 & 9550 & & & \\
\hline Vendée (85) & 14957 & 188 & 123 & & \\
\hline Total & 144747 & 32777 & 915 & 784 & \\
\hline
\end{tabular}

all the questions. The percentages of answers compared with the number of members surveyed varied depending on the departments and questions concerned (Table I). The highest proportions of answers were obtained for the question about angler characteristics in three departments: Loire-Atlantique (61\%), Sarthe (43\%) and Maine-et-Loire (29\%). The percentages of other answers ranged from 0.1 to $2 \%$, depending on the question asked and the department concerned.

\section{> ANGLER CHARACTERISTICS}

\section{Variable category}

The anglers in the Loire basin were not equally stratified in each department (Table II; $\mathrm{chi}^{2}=1233.6, P<0.001$ ). Furthermore, the proportion of anglers who were never (nearly $1 / 3$ of anglers on average) or only occasionally interested in eel (more than half of the anglers on average) was not correlated with the longitudinal gradient of the Loire catchment area (Spearman's correlation test, $r=0.42, P=0.25$ and $r=0.13, P=0.74$, respectively). In contrast, the proportion of anglers often interested in eel was closely correlated with this longitudinal distribution (Spearman's correlation test, $r=-0.76, P=0.02$ ). They accounted for about $20 \%$ of the anglers fishing less than $100 \mathrm{~km}$ from the sea, and less than $10 \%$ of those fishing $200 \mathrm{~km}$ upstream.

\section{The methods used by the different categories of anglers}

The methods that target multi-species were those most often used by anglers in general (Table III). However, the distribution of the methods was different in the three categories $\left(\mathrm{chi}^{2}=25.66, P<0.001\right)$. This showed that multi-species techniques were used more often by anglers who were never interested in eel (by $80 \%$ of them). The distribution of techniques used by the other two categories was the same $\left(\mathrm{chi}^{2}=1.38, P=0.50\right)$. 


\section{Table II}

Mean distance of the department from the tidal limit, and percentage of anglers who are considered to belong to the department. Never: never interested in eel; Occasionally: occasionally interested in eel; Often: often interested in eel.

\section{Tableau II}

Distance moyenne de chaque département à la limite tidale et pourcentage de pêcheurs aux lignes en fonction de leur intérêt à pêcher l'anguille. Never: jamais intéressé par l'anguille; Occasionally: occasionnellement intéressé par l'anguille ; Often : souvent intéressé par l'anguille.

\begin{tabular}{|l|c|c|c|c|}
\hline Name and $\left(\mathrm{n}^{\circ}\right)$ of department & Distance & Never & Occasionally & Often \\
\hline Allier (3) & 550 & 43 & 52 & 4 \\
\hline Indre (36) & 290 & 41 & 57 & 2 \\
\hline Indre-et-Loire (37) & 200 & 42 & 46 & 12 \\
\hline Loir-et-Cher (41) & 250 & 20 & 71 & 8 \\
\hline Loire-Atlantique (44) & 0 & 14 & 67 & 19 \\
\hline Maine-et-Loire (49) & 80 & 30 & 53 & 17 \\
\hline Mayenne (53) & 160 & 43 & 55 & 2 \\
\hline Sarthe (72) & 200 & 15 & 69 & 15 \\
\hline Vendée (85) & 50 & 36 & 47 & 18 \\
\hline Mean \pm sd & & $32 \pm 12$ & $58 \pm 10$ & $11 \pm 7$ \\
\hline
\end{tabular}

\section{Table III}

Percentages of fishing techniques used (multispecies, eel specific or both) according to categories of angler.

\section{Tableau III}

Pourcentages des techniques de pêche utilisées par les différentes catégories de pêcheurs (multiespèce, spécifique à l'anguille ou les deux).

\begin{tabular}{|l|c|c|c|}
\hline & Never & Occasionally & Often \\
\hline Multi fish species & 80.4 & 61.4 & 61.0 \\
\hline Eel specific & 3.6 & 15.4 & 11.9 \\
\hline Both & 16.0 & 23.2 & 27.1 \\
\hline
\end{tabular}

\section{The annual fishing effort}

The number of fishing days significantly increased (ANOVA, $F=45.78, P<0.001$; Tukey post-test, all $P<0.001$ ) with the interest of the anglers in eel: $0.1 \pm 0.7$ days for anglers who were never interested, $9.3 \pm 14.2$ days for those who were occasionally interested, and 40.4 \pm 62.5 days for those who were often interested.

\section{The quantity caught}

The annual mean quantity caught by each angler increased significantly with his interest in the species (ANOVA, $F=45.90, P<0.001$; Tukey post-test, all $P<0.001$ ). It ranged from less than $1 \mathrm{~kg}$ per angler and per year for those who were never interested in eel, to more than $5 \mathrm{~kg}$ per angler and per year for those who were often interested in eel (Table IV). In contrast, for each category of angler, this quantity did not vary between departments (ANOVA, 


\section{Table IV}

Mean \pm sd of weight $(\mathrm{kg})$ of eels fished in 2004 according to department and the category of angler.

Tableau IV

Poids moyen (kg \pm écart-type) des anguilles capturées en 2004 en fonction des départements et des catégories de pêcheurs.

\begin{tabular}{|l|c|c|c|}
\hline Name and $\left(\mathrm{n}^{\circ}\right)$ of department & Never & Occasionally & Often \\
\hline Allier (3) & $1.3 \pm 1.4$ & $5.0 \pm 6.7$ & $3.3 \pm 1.2$ \\
\hline Indre (36) & $0.6 \pm 2.0$ & $3.1 \pm 6.2$ & $17.0 \pm 19.0$ \\
\hline Indre-et-Loire (37) & $0.5 \pm 2.3$ & $2.6 \pm 7.5$ & $2.1 \pm 5.6$ \\
\hline Loir-et-Cher (41) & $1.7 \pm 2.9$ & $2.5 \pm 3.3$ & $3.5 \pm 4.4$ \\
\hline Loir-Atlantique (44) & $0.5 \pm 1.3$ & $2.2 \pm 4.6$ & $8.6 \pm 21.1$ \\
\hline Mayenne (53) & $0.2 \pm 0.4$ & $2.2 \pm 4.1$ & $3.6 \pm 5.4$ \\
\hline Mean \pm sd & $0.8 \pm 1.5$ & $2.5 \pm 5.4$ & $5.3 \pm 14.5$ \\
\hline
\end{tabular}

all $P>0.05$ ), even though anglers looking specifically for eel in Loire-Atlantique and Indre seemed to be more successful.

In the six departments taken into account, it was possible to estimate the total quantity of eels landed. This ranged from 15 metric tons in Mayenne, to more than 70 metric tons in Loire-Atlantique, which corresponded to a mean annual catch of about $2.37 \pm 0.78 \mathrm{~kg}$ by anglers. If extrapolated to the entire Loire basin, the total biomass caught in 2004 by the anglers was about $830 \pm 272$ metric tons.

\section{Eel characteristics}

The mean weight of the eels caught ranged from $0.4 \mathrm{~kg}$ in Loire-Atlantique to $1.2 \mathrm{~kg}$ in the Allier (Figure 2). This mean weight was correlated with the distance from the sea (Spearman's correlation test, $r=0.99, P=0.003$ ).

\section{DISCUSSION}

There are currently 1.5 million anglers in France, which makes recreational fishery very important, and it clearly has economic, social and cultural roles. If the quantity of eels caught by professional fishermen is relatively well established for the estuaries (Castelnaud et al., 1994), and is beginning to be known in freshwater (Feunteun et al., 2008), the catches taken by anglers remain totally unknown on a large scale like the Loire catchment basin. However, anglers outnumber professional fishermen. Despite several sources of bias (the limited number of departments taken into account, a low return rate since the survey was completed on a voluntary basis, reliance on anglers' memories, etc.), this first study shows that it is possible to assess the different angling strategies and the quantity caught by means of a survey. Even though the sample was very small relative to the total angler population, stratification shows that the angler population was representative, particularly in three local areas (Loire-Atlantique, Maine-et-Loire and Sarthe). This approach needs to be developed, but the answer rate varied from 29 to $61 \%$ of the angler population, assuming that the other stratifications and findings were relevant.

It emerged that for more than half of the recreational anglers from the line fishing association, eel was not the main target species, but simply an occasional species caught on 10 days a year. The anglers who were often interested by this species spent more time, nearly 40 days 


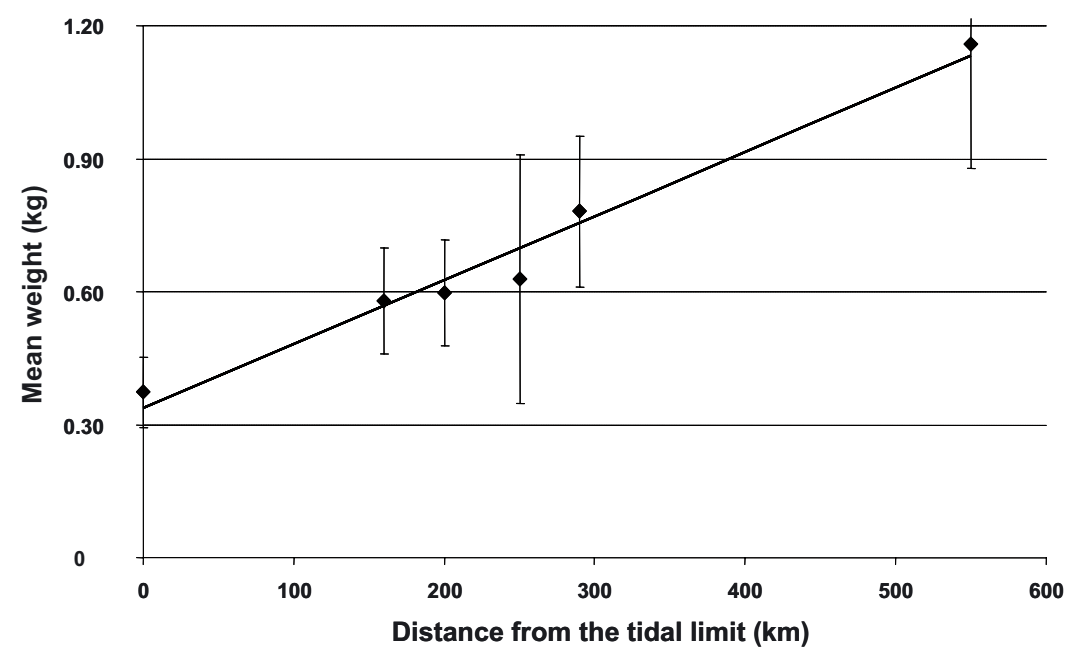

\section{Figure 2}

Mean weight of eel caught $(\mathrm{kg} \pm \mathrm{sd})$ vs. distance from the tidal limit $(\mathrm{km})$.

Figure 2. Poids moyen des anguilles capturées ( $\mathrm{kg} \pm$ écart-type) en fonction de la distance à la limite tidale $(\mathrm{km})$.

mean biomass caught by the anglers increased in relation to the anglers' interest in eel. The mean biomass is around $2.5 \mathrm{~kg}$ per fishermen per year, but it can easily exceed $10 \mathrm{~kg}$ per year for some anglers who look especially for eel, even in the departments far from the sea (for example, the Allier). The interest of anglers in eel was greater in the coastal departments (Loire-Atlantique and Vendée). Indeed, eel is present in high density in the coastal marshes, where it has been shown recently to constitute more than $50 \%$ of the fish biomass (Feunteun et al., 1999). In these areas (such as the "marais de Brière", "marais Breton Vendéen", "marais Poitevin", etc.) the eel has a high conservation value (Laffaille et al., 2004; Baisez and Laffaille, 2005). In fact, various methods of catching eel (line and trap fishing, extensive production in ponds, etc.) have been used since the creation of these systems (Feunteun et al., 1999). This eel fishing was, and still is in some areas, a reason justifying the regular management of marsh waters. Habitat restoration is rarely used to restore eel stocks, despite the belief that habitat degradation is one of the causes of the decline in population. According to Feunteun (2002), this would probably be one of the most promising ways of restoring inland eel stocks. There is also a high level of interest in eel in the departments situated along the Loire River, which is free of obstacles to colonization, and which still has a high density of eel (Lasne and Laffaille, 2008). This interest decreases with the distance from the sea.

The mean weight of eels caught by anglers increased from downstream to upstream in the Loire catchment area. This observation is totally consistent with the distribution of the length (and, by consequence, of the biomass) of the eel in the catchment area as a whole (Rigaud et al. , 2008), and notably in the Loire River (Lasne and Laffaille, 2008).

An assessment of the fishing pressure exerted by anglers on eel has been set up in France (Working Group on Eel, 2008). The total catch of eel landed by French anglers is estimated to

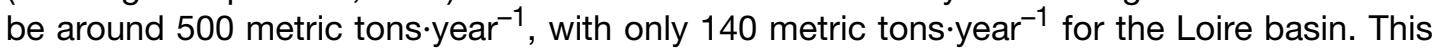
estimate is much lower than our data, because of important differences in this previous study: (1) the mean weight of the eel (less than $130 \mathrm{~g}$ ); (2) the time devoted to fishing (17 fishing sessions per angler, for anglers fishing for eels at least once a year); and (3) the mean biomass per catch (only 0.03 eel per session in departments in which eel are marginal, such as Allier). Moreover, there were fewer than 35000 eel anglers (anglers fishing for eels at least once a year) in the Loire basin. These authors probably only took into account the anglers interested in eel (our last category), who are not very numerous. Our study shows 
that eels are most often an accessory catch, but that they are always kept once caught, and that a lot of anglers are involved.

Another study was carried out by the ONEMA service in 2002 in the local area of LoireAtlantique (Changeux et al., 2003). They stratified the anglers into five categories on the basis of the gear used and their interest in eel fishing. The sample represented $3.7 \%$ of the anglers in the area $(N=833)$. Their catches ranged from 0.06 to 8.42 eels per angler, with mean length of eels caught of about $50 \mathrm{~cm}$ (mean weight about $250 \mathrm{~g}$ ). These observations indicate that the interest these anglers showed in eel fishing was highly variable. The mean number of fishing sessions was comparable with ours: 38 fishing sessions per year. Finally, the total catch was estimated to be 66 metric tons per year for this local area, which was very close to our estimations.

Compared with other fishing activities, our results show that recreational eel fishing activity is very low on the individual scale, but that many anglers fall into this category. Professional fishermen of glass eels catch on average 132 to $200 \mathrm{~kg}$ per fisherman per year (there are approximately 400 fishermen). The professional fishermen of yellow eels catch $150 \mathrm{~kg}$ per year per fisherman in the maritime zone (where there are 30 professional fishermen targeting eels), and $600 \mathrm{~kg}$ per year per fisherman in the freshwater zone (there are 80 of them). The professional fishermen targeting silver eels land on average $4000 \mathrm{~kg}$ per fisherman per year (there are currently 13 working fishermen). Some recreational fishermen also use traps (they number about 3000). They are especially covered by a national survey, which indicates an average catch of $10 \mathrm{~kg}$ per fisherman per year. Unfortunately, other sources of mortality have not been measured.

The simple stratification into three categories of anglers is rather relative, since the terms used in the question "Are you interested in catching eel often, occasionally or never?" were not explicitly quantified. However, this has allowed us to obtain more information, and the definition of the terms appeared to be more reliable than might be supposed, as demonstrated by the distribution per category as a proportion of the number of times when the angler was looking for eel. (This simple stratification allowed us to view the answers as being representative of the whole population of anglers). The preliminary results (the spatial distribution of the angler categories, the time devoted to eel catching by the various categories of anglers, the mean quantities caught by each category of angler, the spatial distribution of the mean eel weight landed) highlighted the consistency of the stratification, which was based on the assumption that the fishing effort, the fishing techniques used and the catches taken were related to the interest that the anglers had in the species.

To improve the accuracy and precision of the results, specific attention will henceforth be devoted to stratification, and especially to increasing the number of answers returned, and the representativeness of the rivers to which the answers relate. Two questions could determine the robustness of the sampling in order to improve the representativeness of the angler population: "Where do the anglers fish (in which rivers)?" and "How many anglers fish in each river?". With regard to how to display the survey, it could be modified in two steps. The first would be to stratify as many anglers as possible into the three categories (using the annual individual fishing permit, for instance). The second would be to ask some of them (a survey of the anglers) by phone or by letter to answer the entire survey. The anglers contacted would be chosen on the basis of the category to which they assign themselves, and the river where they fish.

The data we have obtained has made it possible to estimate eel catches for the whole of the Loire basin. The first estimation obtained in this study is about 830 metric tons $\cdot y e a r^{-1}$, but the associated standard deviation is high, and this estimation needs to be assessed more accurately. The results show a clear relationship between the catch per department and the local characteristics of the eel population, i.e. the change in the average weight (or size) along the downstream to upstream gradient, and the decrease in abundance along this same gradient (for example, see Lasne and Laffaille 2008). These results highlight the limitations of the estimation, since the rivers close to the sea were systematically compared with zones with high densities of eels, without taking into account the parameters 
of accessibility. In order to improve the robustness of the estimation, it is therefore necessary to obtain further information about territories where eel is of particular interest, such as the Maine and Vienne basins, but also in the upstream zones, where eel catches have probably been overestimated.

\section{ACKNOWLEDGEMENTS}

This work could not have been done without the help of the angling federation and the angling clubs of Allier (A.M. Minster), Indre (B. Barbey), Indre-et-Loire (G. Ricou), Loir-et-Cher (I. Parot), Loire-Atlantique (V. Mouren), Maine-et-Loire (Y. Nicolas), Mayenne (M.L. Piau), Sarthe (A. Dieu) and Vendée (D. Bouron). The contributions of the recreational anglers who responded to the survey have been considerable. We would also like to thank the Water Agency, the "Loire Public Establishment", the Pays de la Loire Region and the LOGRAMI association, who funded the eel report card. We thank the anonymous reviewers for their many helpful suggestions.

\section{REFERENCES}

Arlinghaus R., Cooke S.J., Coleman F.C., Figueira W.F., Ueland J.S. and Crowder L.B., 2005. Global impact of recreational fisheries. Science, 307, 1561.

Baisez A. and Laffaille P., 2005. Un outil d'aide à la gestion de l'anguille : le tableau de bord anguille du bassin Loire. Bull. Fr. Pêche Piscic., 378-379, 115-130.

Castelnaud G., Guerault D., Desaunay Y. and Elie P., 1994. Production et abondance de la civelle en France au début des années 90. Bull. Fr. Pêche Piscic., 335, 263-288.

Changeux T., 2002. L'effort de pêche ciblant l'anguille dans les eaux libres françaises en 2000. Rapport Conseil Supérieur de la Pêche, $8 \mathrm{p}$.

Changeux T., Rancon J. and Lelièvre M., 2003. Évaluation des captures d'anguille par les membres des AAPPMA dans le bassin de la Loire. Cas du département de Loire Atlantique. Rapport Conseil Supérieur de la Pêche/LOGRAMI, $23 \mathrm{p}$.

Coleman F.C., Figueira W.F., Ueland J.S. and Crowder L.B., 2004. The impact of United States recreational fisheries on marine fish populations. Science, 305, 1958-1959.

Dekker W., 2000. A Procrustean assessment of the European eel stock. ICES J. Mar. Sci., 57, 938-947.

Dekker W., 2003. Status of the European eel stock and fisheries. In: Aida K., Tsukamoto K. and Yamauchi K. (eds.), Eel biology, Springer-Verlag, Tokyo.

Feunteun E., 2002. Management and restoration of European eel population (Anguilla anguilla): an impossible bargain. Ecol. Eng., 18, 575-591.

Feunteun E., Rigaud C., Elie P. and Lefeuvre J.-C., 1999. Les peuplements piscicoles des marais littoraux endigués atlantiques : un patrimoine à gérer? Le cas du marais de Bourgneuf Machecoul (Loire-Atlantique, France). Bull. Fr. Pêche Piscic., 352, 63-79.

Feunteun E., Robinet T., Lobon-Cervia J., Boury P., Boisneau P. and Acou A., 2008. Indicateurs d'échappement des géniteurs potentiels. In: Adam G., Feunteun E., Prouzet P. and Rigaud C. (eds.), Indicateurs d'abondance et de colonisation, QUAE, Paris, 331-360.

ICES, 1999. Report of the ICES Advisory Committee on Fisheries Management, 1998, International Council for the Exploration of the Sea, Copenhagen. ICES Cooperative Research Report, 229, 819-828.

Laffaille P., Baisez A., Rigaud C. and Feunteun E., 2004. Habitat preferences of different European eel size classes in a reclaimed marsh: a contribution to species and ecosystem conservation. Wetlands, 24, 642-651.

Lasne E. and Laffaille P., 2008. Analysis of distribution patterns of yellow European eels in the Loire catchment using logistic models based on presence-absence of different size-classes. Ecol. Fresh. Fish., 17, 30-37.

Lasne E., Bergerot B., Lek S. and Laffaille P., 2007. Fish zonation and indicator species for the evaluation of the ecological status of rivers: example of the Loire Basin (France). River Res. Appl., 23, 877-890. 
Morales-Nin B., Moranta J., Garcia C., Tugores M.P., Grau A.M., Riera F. and Cerda M., 2005. The recreational fishery off Majorca Island (western Mediterranean): some implications for coastal resource management. ICES J. Mar. Sci., 62, 727-739.

Moriarty C. and Dekker W., 1997. Management of European eel fisheries. Irish Fishery Bulletin, 15, 1-110.

Rigaud C., Laffaille P., Prouzet P., Feunteun E., Diaz E., Castellano J. and De Casamajor M.-N., 2008. Des compléments sur la biologie. In: Adam G., Feunteun E., Prouzet P. and Rigaud C. (eds.), L'anguille européenne, Indicateurs d'abondance et de colonisation, QUAE, Paris, 43-86.

Rosell R., Evans D. and Allen M., 2005. The eel fishery in Lough Neagh, Northern Ireland - an example of sustainable management? Fish. Manag. Ecol., 12, 377-385.

Working Group on Eel, 2008. Country reports. EIFAC/ICES report, 433 p., available at www.ices.dk/reports/acom/2008/wgeel/country_report_2008.pdf. 